\title{
Long-term efficacy and safety of adalimumab in 4-12 year old patients with juvenile idiopathic arthritis
}

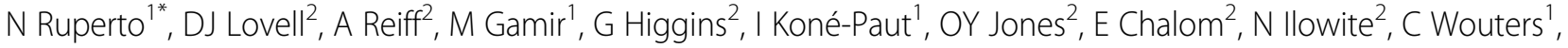 \\ MJ Mcllraith ${ }^{3}$, S Liü ${ }^{4}$, H Kupper ${ }^{5}$, EH Giannini ${ }^{2}$, A Martini $^{1}$ \\ From 18th Pediatric Rheumatology European Society (PReS) Congress \\ Bruges, Belgium. 14-18 September 2011
}

\section{Background}

Adalimumab (ADA) has been shown to be safe and effective in a study of juvenile idiopathic arthritis (JIA) patients aged $4-17$ years at a dose of $24 \mathrm{mg} / \mathrm{m}^{2}$ every other week. ${ }^{1}$

\section{Aim}

To determine the long-term efficacy and safety of ADA in a subgroup of BSA-dosed JIA patients aged 4-12 years.

\section{Methods}

Patients with polyarticular course JIA $(\mathrm{N}=171)$ were enrolled in a phase 3 , randomized-withdrawal, doubleblind (DB), stratified, parallel-group study, which consisted of a 16-wk open-label (OL) lead-in, a 32-wk DB phase, and an up to 5 year OL extension phase that included BSA dosing prior to a switch to fixed dose (FD). Patients on ADA (24 mg/m $\mathrm{m}^{2}$; max dose, $40 \mathrm{mg}$ ) were evaluated based on ACR pediatric response criteria for improvement (ACR Pedi 30/50/70/90) and monitored for adverse events (AEs).

\section{Results}

Subjects in the 4-12-year-old subgroup $(n=41)$ were $73 \%$ female and $98 \%$ white, with a mean age of 9 years. At baseline, mean PhyGA was 58.1, mean PaGA was 47.9, AJC was 18.6, and DI-CHAQ was 1.0. ACR Pedi 30/50/ $70 / 90$ responses at wk 106 (Table) were comparable to completer patients $(n=62)$ in the overall population who reached $\sim 240$ wks in the OL extension FD phase $(95 \% /$

\footnotetext{
* Correspondence: nicolaruperto@ospedale-gaslini.ge.it

${ }^{1}$ PRINTO-IRCCS Genova, Italy

Full list of author information is available at the end of the article
}

90\%/82\%/69\%). Improvements in core disease activity/ severity variables were maintained throughout the study (Table 1). The most common AEs were infections and injection site reactions; there were no opportunistic infections, malignancies, or deaths. One patient in the 4-12-year-old subgroup discontinued due to AEs (viral illness and hydrocephalus secondary to mechanical complications of nervous system device).

\section{Conclusions}

ADA was efficacious and well tolerated in a BSA-dosed JIA subpopulation aged 4-12 years. ACR Pedi 30/50/70/ 90 responses were maintained through 106 weeks. Overall, efficacy was comparable to the entire study population, in whom maintenance of response was observed throughout the entire study with ADA for up to 6 years.

Table 1 ACR indicates American College of Rheumatology; AJC, active joint count; DI-CHAQ, disability index of childhood health assessment questionnaire; PaGA, parent global assessment of wellbeing; PhyGA, physician's global assessment of disease activity

\begin{tabular}{llllll}
\hline Time points & ACR 30/50/70/90 & PhyGA & PaGA & AJC & DI-CHAQ \\
\hline Week 16 & $100 / 88 / 63 / 39$ & 12.7 & 12.2 & 5.1 & 0.4 \\
\hline Week 48 & $100 / 96 / 92 / 69$ & 6.3 & $\mathbf{8 . 3}$ & 2.9 & 0.2 \\
\hline Week 106 & $100 / 96 / 96 / 71$ & 5.9 & 5.0 & 1.2 & 0.1
\end{tabular}

$\%$ of Pts Aged 4-12 Years Achieving ACR Pedi and Mean Values in Disease Activity/Severity Variables by ADA Exposure Throughout the Study 


\section{Author details}

'PRINTO-IRCCS Genova, Italy. ${ }^{2}$ PRCSG-Cincinnati Children's Hospital Medical

Center, Cincinnati, USA. ${ }^{3}$ Abbott, Rungis, France. ${ }^{4}$ Abbott, Abbott Park, USA.

${ }^{5}$ Abbott, Ludwigshafen, Germany.

Published: 14 September 2011

\section{Reference}

1. Lovell DJ, et al: NEJM. 2008, 359:810-820.

doi:10.1186/1546-0096-9-S1-O26

Cite this article as: Ruperto et al:: Long-term efficacy and safety of

adalimumab in 4-12 year old patients with juvenile idiopathic arthritis.

Pediatric Rheumatology 2011 9(Suppl 1):O26.

Submit your next manuscript to BioMed Central and take full advantage of:

- Convenient online submission

- Thorough peer review

- No space constraints or color figure charges

- Immediate publication on acceptance

- Inclusion in PubMed, CAS, Scopus and Google Scholar

- Research which is freely available for redistribution

Submit your manuscript at www.biomedcentral.com/submit
C Biomed Central 